\title{
Yue Zhu, Wing Au, Greg Yates, University Students' Self-control and Self-regulated Learning in a Blended Course (Samokontrola oraz automotywacja studentów uczących się z wykorzystaniem metod blended learning), „The Internet and Higher Education" 2016, vol. 30, s. 54-62, DOI: 10.1016/j.iheduc.2016.04.001.
}

Autorzy artykułu podjęli się analizy wpływu samokontroli na wyniki nauczania studentów w środowisku blended learning. Na wstępie wyjaśniaja, że blended learning to mieszana metoda nauczania, łącząca tradycyjny bezpośredni kontakt $\mathrm{z}$ prowadzącym z nauką prowadzoną $\mathrm{w}$ formie zdalnej (e-learning/mobile learning), oparta na wykorzystaniu komputera oraz Internetu. Badacze wskazują, że studenci w procesie nauczania metodą blended learning mają dostęp do materiałów dydaktycznych on-line, jak również mogą kontaktować się z wykładowcami za pośrednictwem Internetu, jednocześnie uczestnicząc w zajęciach prowadzonych tradycyjnie "twarzą w twarz". Ze względu na swój charakter nauczanie metodą blended learning stwarza większe wymagania w zakresie zaangażowania studentów w proces nauczania oraz większej motywacji i samokontroli. W tej metodzie studenci muszą samodzielnie wykonać pierwszy krok w stronę nauczania, muszą określić swoje potrzeby i cele.

Autorzy wskazują na wieloaspektowość i różnice indywidualne w zakresie samokontroli studentów, którzy wyznaczają sobie inne długoterminowe cele nauczania, inaczej opierają się pokusom bądź odsuwają w czasie gratyfikację, kontrolując impulsy emocjonalne. Badacze podkreślają przy tym, że samokontrola człowieka odnosi się do serii ćwiczeń w zakresie kontroli nad samym sobą oraz w obszarze aktywacji najbardziej efektywnych strategii, w celu utrzymania i uzyskania wyników jak najbardziej zgodnych ze standardami. W nauczaniu zaś samokontrola odnosi się wprost do samogenerowania myśli oraz planowanych działań, nakierowanych na osiągnięcie celu nauczania.

Badacze testowali obszar samokontroli nauczania na próbie 74 studentów drugiego roku, wykorzystujących blended learning jako metodę nauczania w zakresie 
kursu ICT. Badanie opierało się na wypełnianym na początku kwestionariuszu ankiety dotyczącym oceny zdolności w zakresie samokontroli i samomotywacji. Drugą ważną płaszczyzną badania były raporty na temat doświadczeń tych studentów.

Badacze zidentyfikowali wysoki wpływ samokontroli na wyniki nauczania studentów z badanej próby, przy czym pozytywne efekty samokontroli uczniów były (i są) ograniczane przez samoregulację uczenia się oraz przez zakres udziału w kursach.

Badacze podkreślają, że samokontrola ma istotny wpływ na wyniki nauczania już od najmłodszych lat i zwykle przyczynia się do lepszych ocen uczniów, także na wczesnym etapie dorosłości.

Zgodnie z wynikami badań przedstawionych w opracowaniu studenci szkół wyższych powinni być zdolni do efektywnego wykorzystywania strategii samokontroli dla lepszego uczenia się, tym bardziej że zadania dydaktyczne wykonywane są przy mniejszym udziale nadzoru ze strony wykładowców, w przeciwieństwie do nauczania na poziomie szkoły podstawowej czy też średniej.

Monika Kotowska-Lewińska

DOI: $10.14746 /$ spp.2016.3.15.13 